\title{
Dynamics of the transition of corporate governance models of the Republic of Tatarstan from "oligarchic" to innovative ones through strategic regional management
}

\author{
Nazilya Zarifovna Sayfudinova ${ }^{1,2, *}$, Daniya Kalimullovna Shigapova $^{3}$, Aleksej Vasilevich \\ Bolshov $^{4}$, Aelina Askhatovna Barieva ${ }^{3}$, and Irina Anatolievna Akhmetova ${ }^{4}$ \\ ${ }^{1}$ The Center for Advanced Economic Research of the Academy of Sciences of the Republic of \\ Tatarstan \\ ${ }^{2}$ Kazan State Power Engineering University, Kazan \\ ${ }^{3}$ Kazan State University of Architecture and Engineering, Kazan \\ ${ }^{4}$ Kazan (Volga Region) Federal University, Kazan
}

\begin{abstract}
The article examines the dynamics of the transformation of corporate governance in the Republic of Tatarstan. The author's approach is presented, according to which the strategic regional development affects the corporate governance system of the organization. The analysis of enterprises from various industries of the Republic of Tatarstan has been carried out and the leading ones have been selected. Further, according to the indicators of these organizations, calculations were made using the Altman five-factor model for 5 years. The chosen model and time period allow to reliably trace the dynamics of the company's economic potential and the results of its development for the reporting periods. The obtained results of the analysis and calculations showed that the corporate governance of enterprises changed the trend and began to move to an innovative type. Regional development strategies have a positive impact on corporate governance of enterprises. Moreover, an important point is that by means of regional development strategies, organizations themselves are interested in improving the corporate governance system. Thus, the impact on enterprises and their changes do not occur "top-down" (authoritarian, edifying), but "bottom-up" (the organization itself seeks to meet modern requirements in order to be economically efficient).
\end{abstract}

\section{Introduction}

In recent decades, every year more and more interest has been shown in corporate governance of the enterprise. However, unfortunately, the problems with its formation and development did not diminish. As before, the efficiency and investment attractiveness of many companies remains low. Meanwhile, this situation is a consequence of the

\footnotetext{
*Corresponding author: nazilya_sf@mail.ru
} 
underdevelopment of corporate governance in organizations or its absence at all. And as a result - the inconsistency of the interests of all participants in the enterprise [3].

In our opinion, many enterprises are faced with a problem in the form of an "oligarchic" corporate governance system, which was especially common about 2015. Under this model, governance is concentrated in the hands of a small group of citizens. In such a situation, power and capital serve personal and group interests, i.e. majority shareholders exploit the business through, for example, restricting access to the register of shareholders, buying up shares from minority shareholders, entering into alliances with "friendly" joint stock companies. This state of affairs leads to the formation of a contradictory corporate governance system [1].

In this regard, there is a need to adjust and improve: the efficiency of corporate governance at enterprises, control over its implementation, setting new tasks and goals in observing the interests of all parties (board, supervisory board, shareholders). As well as the transition from an outdated and obsolete model of company operation to an innovationoriented one, which will increase investor confidence.

The foregoing determines the relevance of the study and its practical significance.

\section{Materials and methods}

Within the framework of this paper, we have investigated the change in corporate governance through the created programs and strategies both at the state and regional levels (on the example of the Republic of Tatarstan), which induce the transition to an innovative model of corporate governance.

To obtain the results, the five-factor Altman z-model was chosen, which allows us to determine the "disturbing" factors of the enterprise. Out of 22 financial coefficients, the author of the model singled out 5 main ones, on which the probability of bankruptcy most depends, according to which the weight coefficients are calculated. If they turn out to be in the "positive" limits or positive dynamics is observed, then, accordingly, this will show that the company is effective and follows an innovative path, since this is one of the defining indicators for investment.

The generally accepted Altman z-model is as follows:

$$
\mathrm{Z}=1,2 * \mathrm{X} 1+1,4 * \mathrm{X} 2+3,3 * \mathrm{X} 3+0,6 * \mathrm{X} 4+\mathrm{X} 5
$$

where [4]:

$\mathrm{Z}$ is the coefficient of the probability of bankruptcy;

$\mathrm{X} 1$ is the ratio of current assets to the total value of the company's assets;

$\mathrm{X} 2$ is the ratio of the company's retained earnings to its total asset value;

$\mathrm{X} 3$ is the ratio of operating profit to the total assets of the company;

$\mathrm{X} 4$ is the ratio of the market value of the company's capital to its total debt;

$\mathrm{X} 5$ is the ratio of the company's revenue to the total value of its assets.

If $\mathrm{Z}$ is less than 1.8 , then the probability of bankruptcy is very high; from 1.8 to 2.7 average;

from 2.8 to 2.9 is small;

above 3-bankruptcy is unlikely.

According to the five-factor model, bankruptcy can be predicted in one year with an accuracy of $90-95 \%$, in two years - up to $70-80 \%$, in three years - up to $48-50 \%$.

Altman's index is a function of some indicators that characterize the economic potential of a company and its performance over the past period. The critical value of the $\mathrm{Z}$ index was calculated by Altman from the data of a static sample and amounted to 2.675. The calculated value of the creditworthiness index for a particular company is compared with 
this value. This allows you to draw a line between companies and make a judgment about the possible bankruptcy of some in the near future $(2-3$ years $)(Z<2.675)$ and a fairly stable financial position of others $(Z>2.675)$.

Next, we will test this model for 2015-2019 based on indicators that are publicly available in the financial statements of selected enterprises.

Thus, in our case, we will analyze and compare the indicators of past periods, which will allow us to trace the dynamics over 5 years, that is, what was and what we came to.

\section{Results and discussion}

When analyzing the impact of strategic regional planning on the corporate governance system, we used the Altman model and selected the following companies - leaders in their industry:

1. PJSC "KAMAZ".

2. PJSC Tatneft.

3. PJSC Nizhnekamskneftekhim.

4. PJSC "Kazanorgsintez".

5. JSC "Network company".

6. JSC "Elekon".

We calculated the values of the variables that will be used to determine the $\mathrm{Z}$ coefficient based on financial indicators presented by organizations in the section "on disclosure of information" within the framework of corporate governance. The variables are presented for each facility in Tables 1-6.

Table 1. Values of variables for calculating the Z coefficient of Kamaz PJSC from 2015 to 2019. [5]

\begin{tabular}{|c|c|c|c|c|c|c|}
\hline \multicolumn{7}{|c|}{ JSC "KAMAZ" } \\
\hline Ser. No. & Variable & $\mathbf{2 0 1 5}$ & $\mathbf{2 0 1 6}$ & $\mathbf{2 0 1 7}$ & $\mathbf{2 0 1 8}$ & $\mathbf{2 0 1 9}$ \\
\hline 1 & X1 & 0.02 & 0.25 & 0.3 & 0.33 & 0.37 \\
\hline 2 & X2 & 0 & 0.01 & 0.02 & 0.02 & 0.04 \\
\hline 3 & X3 & 0.01 & 0.02 & 0.04 & 0.02 & 0.04 \\
\hline 4 & X4 & 0.33 & 0.28 & 0.27 & 0.2 & 0.2 \\
\hline 5 & X5 & 0.88 & 0.98 & 0.98 & 0.95 & 0.94 \\
\hline
\end{tabular}

Table 2. Values of variables for calculating the $Z$ coefficient of Tatneft PJSC from 2015 to 2019. [6]

\begin{tabular}{|c|c|c|c|c|c|c|}
\hline \multicolumn{7}{|c|}{ PJSC "Tatneft" } \\
\hline Ser. No. & Variable & $\mathbf{2 0 1 5}$ & $\mathbf{2 0 1 6}$ & $\mathbf{2 0 1 7}$ & $\mathbf{2 0 1 8}$ & $\mathbf{2 0 1 9}$ \\
\hline 1 & $\mathrm{X} 1$ & 0.07 & 0.08 & 0.08 & 0.09 & 0.09 \\
\hline 2 & $\mathrm{X} 2$ & 0.12 & 0.15 & 0.2 & 0.22 & 0.28 \\
\hline 3 & $\mathrm{X} 3$ & 0.2 & 0.4 & 0.3 & 0.4 & 0.6 \\
\hline 4 & $\mathrm{X} 4$ & 0.4 & 0.3 & 0.41 & 0.48 & 0.5 \\
\hline 5 & $\mathrm{X} 5$ & 0.8 & 0.85 & 0.84 & 0.91 & 0.98 \\
\hline
\end{tabular}

Table 3. Values of variables for calculating the Z coefficient of PJSC "Nizhnekamskneftekhim" from 2015 to 2019 [7]

\begin{tabular}{|c|c|c|c|c|c|c|}
\hline \multicolumn{7}{|c|}{ PJSC Nizhnekamskneftekhim" } \\
\hline Ser. No. & Variable & $\mathbf{2 0 1 5}$ & $\mathbf{2 0 1 6}$ & $\mathbf{2 0 1 7}$ & $\mathbf{2 0 1 8}$ & $\mathbf{2 0 1 9}$ \\
\hline 1 & $\mathrm{X} 1$ & 0.05 & 0.07 & 0.06 & 0.08 & 0.09 \\
\hline 2 & $\mathrm{X} 2$ & 0.15 & 0.2 & 0.23 & 0.25 & 0.41 \\
\hline 3 & $\mathrm{X} 3$ & 0.32 & 0.46 & 0.4 & 0.44 & 0.51 \\
\hline 4 & $\mathrm{X} 4$ & 0.3 & 0.2 & 0.28 & 0.35 & 0.34 \\
\hline 5 & $\mathrm{X} 5$ & 0.71 & 0.78 & 0.85 & 0.91 & 0.9 \\
\hline
\end{tabular}


Table 4. Values of variables for calculating the Z coefficient of Kazanorgsintez PJSC from 2015 to $2019[8]$

\begin{tabular}{|c|c|c|c|c|c|c|}
\hline \multicolumn{7}{|c|}{ PJSC "Kazanorgsintez" } \\
\hline Ser. No. & Variable & $\mathbf{2 0 1 5}$ & $\mathbf{2 0 1 6}$ & $\mathbf{2 0 1 7}$ & $\mathbf{2 0 1 8}$ & $\mathbf{2 0 1 9}$ \\
\hline 1 & $\mathrm{X} 1$ & 0.07 & 0.06 & 0.05 & 0.08 & 0.08 \\
\hline 2 & $\mathrm{X} 2$ & 0.2 & 0.2 & 0.4 & 0.51 & 0.5 \\
\hline 3 & $\mathrm{X} 3$ & 0.2 & 0.24 & 0.26 & 0.3 & 0.31 \\
\hline 4 & $\mathrm{X} 4$ & 0.35 & 0.38 & 0.44 & 0.42 & 0.4 \\
\hline 5 & $\mathrm{X} 5$ & 0.82 & 0.8 & 0.85 & 0.87 & 0.91 \\
\hline
\end{tabular}

Table 5. Values of variables for calculating the Z coefficient of JSC "Network Company" from 2015 to 2019 [9]

\begin{tabular}{|c|c|c|c|c|c|c|}
\hline \multicolumn{7}{|c|}{ JSC "Network company" } \\
\hline Ser. No. & Variable & $\mathbf{2 0 1 5}$ & $\mathbf{2 0 1 6}$ & $\mathbf{2 0 1 7}$ & $\mathbf{2 0 1 8}$ & $\mathbf{2 0 1 9}$ \\
\hline 1 & $\mathrm{X} 1$ & 0.08 & 0.06 & 0.06 & 0.07 & 0.08 \\
\hline 2 & $\mathrm{X} 2$ & 0.18 & 0.22 & 0.27 & 0.34 & 0.42 \\
\hline 3 & $\mathrm{X} 3$ & 0.19 & 0.19 & 0.23 & 0.3 & 0.29 \\
\hline 4 & $\mathrm{X} 4$ & 0.4 & 0.32 & 0.35 & 0.42 & 0.5 \\
\hline 5 & $\mathrm{X} 5$ & 0.89 & 0.9 & 0.95 & 0.98 & 0.98 \\
\hline
\end{tabular}

Table 6. The values of the variables for calculating the Z coefficient of JSC "Elecon" from 2015 to 2019. [10]

\begin{tabular}{|c|c|c|c|c|c|c|}
\hline \multicolumn{7}{|c|}{ JSC "Elecon" } \\
\hline Ser. No. & Variable & $\mathbf{2 0 1 5}$ & $\mathbf{2 0 1 6}$ & $\mathbf{2 0 1 7}$ & $\mathbf{2 0 1 8}$ & $\mathbf{2 0 1 9}$ \\
\hline 1 & $\mathrm{X} 1$ & 0.03 & 0.04 & 0.04 & 0.06 & 0.07 \\
\hline 2 & $\mathrm{X} 2$ & 0.1 & 0.18 & 0.19 & 0.2 & 0.25 \\
\hline 3 & $\mathrm{X} 3$ & 0.2 & 0.19 & 0.22 & 0.2 & 0.3 \\
\hline 4 & $\mathrm{X} 4$ & 0.31 & 0.3 & 0.34 & 0.3 & 0.39 \\
\hline 5 & $\mathrm{X} 5$ & 0.81 & 0.85 & 0.86 & 0.9 & 0.92 \\
\hline
\end{tabular}

For each of these organizations, the $\mathrm{Z}$ coefficient was calculated $(\mathrm{Z1}, \mathrm{Z} 2, \mathrm{Z3}, \mathrm{Z4}, \mathrm{Z5}$, Z6 correspond to the ordinal number of enterprises represented in the list of enterprises), which are presented below.

2015:

$\mathrm{Z} 1=1,2 * \mathrm{X} 1+1,4 * \mathrm{X} 2+3,3 * \mathrm{X} 3+0,6 * \mathrm{X} 4+\mathrm{X} 5=1,2 * 0,02+1,4 * 0+3,3 * 0,1+0,6 * 0,33+0,88=1$, 14 ;

$\mathrm{Z} 2=1,2 * \mathrm{X} 1+1,4 * \mathrm{X} 2+3,3 * \mathrm{X} 3+0,6 * \mathrm{X} 4+\mathrm{X} 5=1,2 * 0,07+1,4 * 0,12+3,3 * 0,2+0,6 * 0,4+0,8=1$, 95 ;

$\mathrm{Z} 3=1,2 * \mathrm{X} 1+1,4 * \mathrm{X} 2+3,3 * \mathrm{X} 3+0,6 * \mathrm{X} 4+\mathrm{X} 5=1,2 * 0,05+1,4 * 0,15+3,3 * 0,32+0,6 * 0,3+0,71$ $=2,21$;

$\mathrm{Z} 4=1,2 * \mathrm{X} 1+1,4 * \mathrm{X} 2+3,3 * \mathrm{X} 3+0,6 * \mathrm{X} 4+\mathrm{X} 5=1,2 * 0,07+1,4 * 0,2+3,3 * 0,2+0,6 * 0,35+0,82=$ 2,05 ;

$\mathrm{Z} 5=1,2 * \mathrm{X} 1+1,4 * \mathrm{X} 2+3,3 * \mathrm{X} 3+0,6 * \mathrm{X} 4+\mathrm{X} 5=1,2 * 0,08+1,4 * 0,18+3,3 * 0,19+0,4 * 0,4+0,89$ $=2,09$;

$\mathrm{Z} 6=1,2 * \mathrm{X} 1+1,4 * \mathrm{X} 2+3,3 * \mathrm{X} 3+0,6 * \mathrm{X} 4+\mathrm{X} 5=1,2 * 0,03+1,4 * 0,1+3,3 * 0,2+0,6 * 0,31+0,81=$ 1,83 ;

2016:

$\mathrm{Z} 1=1,2 * \mathrm{X} 1+1,4 * \mathrm{X} 2+3,3 * \mathrm{X} 3+0,6 * \mathrm{X} 4+\mathrm{X} 5=1,2 * 0,25+1,4 * 0,01+3,3 * 0,02+0,6 * 0,28+0,9$ $8=1,96$; 2,0 ;

$\mathrm{Z} 2=1,2 * \mathrm{X} 1+1,4 * \mathrm{X} 2+3,3 * \mathrm{X} 3+0,6 * \mathrm{X} 4+\mathrm{X} 5=1,2 * 0,08+1,4 * 0,15+3,3 * 0,4+0,6 * 0,3+0,82=$

$\mathrm{Z} 3=1,2 * \mathrm{X} 1+1,4 * \mathrm{X} 2+3,3 * \mathrm{X} 3+0,6 * \mathrm{X} 4+\mathrm{X} 5=1,2 * 0,07+1,4 * 0,2+3,3 * 0,46+0,2 * 0,31+0,78$ $=2,76$; 
$\mathrm{Z} 4=1,2 * \mathrm{X} 1+1,4 * \mathrm{X} 2+3,3 * \mathrm{X} 3+0,6 * \mathrm{X} 4+\mathrm{X} 5=1,2 * 0,06+1,4 * 0,2+3,3 * 0,24+0,6 * 0,38+0,8=$ 2,17 ;

$\mathrm{Z} 5=1,2 * \mathrm{X} 1+1,4 * \mathrm{X} 2+3,3 * \mathrm{X} 3+0,6 * \mathrm{X} 4+\mathrm{X} 5=1,2 * 0,06+1,4 * 0,22+3,3 * 0,19+0,6 * 0,32+0,9$ $=2,1$;

$\mathrm{Z} 6=1,2 * \mathrm{X} 1+1,4 * \mathrm{X} 2+3,3 * \mathrm{X} 3+0,6 * \mathrm{X} 4+\mathrm{X} 5=1,2 * 0,04+1,4 * 0,18+3,3 * 0,19+0,6 * 0,3+0,85$ $=1,96$.

2017:

$\mathrm{Z} 1=1,2 * \mathrm{X} 1+1,4 * \mathrm{X} 2+3,3 * \mathrm{X} 3+0,6 * \mathrm{X} 4+\mathrm{X} 5=1,2 * 0,3+1,4 * 0,02+3,3 * 0,04+0,6 * 0,27+0,98$ $=2,29$;

$\mathrm{Z} 2=1,2 * \mathrm{X} 1+1,4 * \mathrm{X} 2+3,3 * \mathrm{X} 3+0,6 * \mathrm{X} 4+\mathrm{X} 5=1,2 * 0,08+1,4 * 0,21+3,3 * 0,3+0,6 * 0,41+0,84$ $=2,46$;

$\mathrm{Z} 3=1,2 * \mathrm{X} 1+1,4 * \mathrm{X} 2+3,3 * \mathrm{X} 3+0,6 * \mathrm{X} 4+\mathrm{X} 5=1,2 * 0,6+1,4 * 0,23+3,3 * 0,04+0,6 * 0,44+0,85$ $=2,76$;

$\mathrm{Z} 4=1,2 * \mathrm{X} 1+1,4 * \mathrm{X} 2+3,3 * \mathrm{X} 3+0,6 * \mathrm{X} 4+\mathrm{X} 5=1,2 * 0,05+1,4 * 0,4+3,3 * 0,26+0,6 * 0,44+0,85$ $=2,45$;

$\mathrm{Z} 5=1,2 * \mathrm{X} 1+1,4 * \mathrm{X} 2+3,3 * \mathrm{X} 3+0,6 * \mathrm{X} 4+\mathrm{X} 5=1,2 * 0,06$

$5+1,4 * 0,27+3,3 * 0,23+0,6 * 0,35+0,95=2,37$;

$\mathrm{Z} 6=1,2 * \mathrm{X} 1+1,4 * \mathrm{X} 2+3,3 * \mathrm{X} 3+0,6 * \mathrm{X} 4+\mathrm{X} 5=1,2 * 0,04+1,4 * 0,19+3,3 * 0,22+0,6 * 0,34+0,8$ $6=2,11$;

2018

$\mathrm{Z} 1=1,2 * \mathrm{X} 1+1,4 * \mathrm{X} 2+3,3 * \mathrm{X} 3+0,6 * \mathrm{X} 4+\mathrm{X} 5=1,2 * 0,33+1,4 * 0,02+3,3 * 0,02+0,6 * 0,22+0,9$ $5=1,86$;

$\mathrm{Z} 2=1,2 * \mathrm{X} 1+1,4 * \mathrm{X} 2+3,3 * \mathrm{X} 3+0,6 * \mathrm{X} 4+\mathrm{X} 5=1,2 * 0,02+1,4 * 0,22+3,3 * 0,4+0,6 * 0,48+0,91$ $=2,94$;

$\mathrm{Z} 3=1,2 * \mathrm{X} 1+1,4 * \mathrm{X} 2+3,3 * \mathrm{X} 3+0,6 * \mathrm{X} 4+\mathrm{X} 5=1,2 * 0,08+1,4 * 0,25+3,3 * 0,44+0,6 * 0,35+0,9$ $1=3,01$;

$\mathrm{Z} 4=1,2 * \mathrm{X} 1+1,4 * \mathrm{X} 2+3,3 * \mathrm{X} 3+0,6 * \mathrm{X} 4+\mathrm{X} 5=1,2 * 0,08+1,4 * 0,51+3,3 * 0,3+0,6 * 0,42+0,87$ $=2,91$;

$\mathrm{Z} 5=1,2 * \mathrm{X} 1+1,4 * \mathrm{X} 2+3,3 * \mathrm{X} 3+0,6 * \mathrm{X} 4+\mathrm{X} 5=1,2 * 0,07+1,4 * 0,34+3,3 * 0,3+0,6 * 0,42+0,98$ $=2,53$;

$\mathrm{Z} 6=1,2 * \mathrm{X} 1+1,4 * \mathrm{X} 2+3,3 * \mathrm{X} 3+0,6 * \mathrm{X} 4+\mathrm{X} 5=1,2 * 0,06+1,4 * 0,22+3,3 * 0,2+0,6 * 0,3+0,9=2$, 09.

2019

$\mathrm{Z} 1=1,2 * \mathrm{X} 1+1,4 * \mathrm{X} 2+3,3 * \mathrm{X} 3+0,6 * \mathrm{X} 4+\mathrm{X} 5=1,2 * 0,37+1,4 * 0,04+3,3 * 0,04+0,6 * 0,2+0,94$ $=1,32$;

$\mathrm{Z} 2=1,2 * \mathrm{X} 1+1,4 * \mathrm{X} 2+3,3 * \mathrm{X} 3+0,6 * \mathrm{X} 4+\mathrm{X} 5=1,2 * 0,09+1,4 * 0,28+3,3 * 0,6+0,6 * 0,5+0,98=$ 3,76 ;

$\mathrm{Z} 3=1,2 * \mathrm{X} 1+1,4 * \mathrm{X} 2+3,3 * \mathrm{X} 3+0,6 * \mathrm{X} 4+\mathrm{X} 5=1,2 * 0,09+1,4 * 0,04+3,3 * 0,51+0,6 * 0,34+0,9$ $=3,43$;

$\mathrm{Z} 4=1,2 * \mathrm{X} 1+1,4 * \mathrm{X} 2+3,3 * \mathrm{X} 3+0,6 * \mathrm{X} 4+\mathrm{X} 5=1,2 * 0,08+1,4 * 0,5+3,3 * 0,31+0,6 * 0,4+0,91=$ 2,93 ;

$\mathrm{Z} 5=1,2 * \mathrm{X} 1+1,4 * \mathrm{X} 2+3,3 * \mathrm{X} 3+0,6 * \mathrm{X} 4+\mathrm{X} 5=1,2 * 0,08+1,4 * 0,42+3,3 * 0,29+0,6 * 0,5+0,98$ $=2,92$;

$\mathrm{Z} 6=1,2 * \mathrm{X} 1+1,4 * \mathrm{X} 2+3,3 * \mathrm{X} 3+0,6 * \mathrm{X} 4+\mathrm{X} 5=1,2 * 0,07+1,4 * 0,25+3,3 * 0,3+0,6 * 0,39+0,92$ $=2,57$.

Having calculated the probability of bankruptcy for each enterprise in dynamics over 5 years, the summary information presented in Table 7 was generated. 
Table 7. Summary table for calculating the probability of occurrence of enterprises from 2015 to 2019

\begin{tabular}{|c|l|c|c|c|c|c|}
\hline $\begin{array}{c}\text { Ser. } \\
\text { No. }\end{array}$ & Name of the organization & $\mathbf{2 0 1 5}$ & $\mathbf{2 0 1 6}$ & $\mathbf{2 0 1 7}$ & $\mathbf{2 0 1 8}$ & $\mathbf{2 0 1 9}$ \\
\hline 1 & JSC "KAMAZ" & 1.14 & 1.96 & 2.29 & 1.86 & 1.32 \\
\hline 2 & PJSC "Tatneft" & 1.95 & 2.00 & 2.46 & 2.93 & 3.76 \\
\hline 3 & $\begin{array}{l}\text { PJSC } \\
\text { "Nizhnekamskneftekhim". }\end{array}$ & 2.21 & 2.76 & 2.76 & 3.01 & 3.43 \\
\hline 4 & PJSC Kazanorg-Sintez. & 2.05 & 2.17 & 2.45 & 2.91 & 2.93 \\
\hline 5 & JSC "Network company". & 2.09 & 2.1 & 2.37 & 2.53 & 2.92 \\
\hline 6 & JSC "Elecon" & 1.83 & 1.96 & 2.11 & 2.09 & 2.57 \\
\hline
\end{tabular}

As can be seen from Table 7, the value of the probability of bankruptcy for most enterprises by 2019 exceeded the minimum allowable value -2.675 . The greatest success in corporate governance was achieved by PJSC Tatneft and PJSC Nizhnekamskneftekhim, whose Z coefficients exceeded 3. PJSC "Kazanorgsintez" and OJSC "Network Company" for 5 years got out of the critical situation and were able to become resistant to bankruptcy enterprises. During the period under review, JSC Elecon has shown a positive dynamics of transformation of the corporate governance system, as evidenced by the value of the coefficient, which in 2019 approached the threshold value of the financial stability of the enterprise. The only organization from the considered ones showed not the best results PJSC "Kamaz". We are inclined to assume that the current position of the company in the automotive market has a great influence. Recently, the machines produced are in less demand, there is no need in progress, which only confirms our hypothesis that the innovative way of the company's development leads to a more successful development of the corporate governance system and the investment attractiveness of the organization.

Thus, we can conclude that corporate governance in the Republic of Tatarstan has significantly changed for the better over the past 5 years. The corporate value system is changing, as evidenced by the change in financial indicators and calculated values. Companies are beginning to look not to the present, but to the future - a strategic vision [11]. That is, not "pulling out" the maximum possible profit today, but working for the future, keeping up with the times.

\section{Conclusion}

In our opinion, on the basis of the work done, the following conclusions and recommendations are logical. Today, corporate governance plays a critical role in the development of an organization. The considered companies are trying to maintain leading positions in the industries of their activity, as evidenced by the analysis of indicators and their calculation. The probability of bankruptcy of enterprises decreased every year. Accordingly, it can be argued that the models of corporate governance are changing in the new economic conditions. And they change in a positive direction, but only for those who observe the "laws" of the market and are engaged in continuous development. This is largely facilitated by external influence in the form of new opportunities - this is the development of the region [2]. In the last decade, the Republic of Tatarstan has taken a competent course of strategic development, which contributes to the improvement of all areas of life. This directly applies to the enterprises that are motivated to meet modern requirements for companies. Therefore, we can conclude that strategic regional development contributes to the improvement and promotion of the corporate development system, which, using the example of the Republic of Tatarstan, showed how many organizations managed to improve their results from the "oligarchic" model over 5 years by 
switching to a new innovative path. And we recommend that enterprises wishing to achieve success turn to their corporate governance system and choose an innovative way of development.

\section{References}

1. A. Asghar, S. Sajjad, A. Shahzad, B.T. Matemilola, Role of discretionary earning management in corporate governance-value and corporate governance-risk relationships, 564 (2020)

2. M.R Safiullin, Development of a development model for the Republic of Tatarstan (2007)

3. M.R Safiullin M.R. Zainullina, System-functional macroeconomic modeling of the development of the Russian Federation (2012)

4. 4.A.S. Mitrofanova, D.A. Pantyukhova, S.N. Khobotova, Application of Altman's model and methods of economic analysis to determine the financial risks of an enterprise on the example of PJSC "Lukoil" (2017)

5. Site of Kamaz PJSC, section "on information disclosure", https://kamaz.ru/

6. Site of Tatneft PJSC, section "on information disclosure", https://www.tatneft.ru/

7. Site of Nizhnekamskneftekhim PJSC, section "on information disclosure", https://www.nknh.ru/

8. Site of Kazanorgsintez PJSC, section "on information disclosure", https://www.kazanorgsintez.ru/

9. Site of Grid Company JSC, section "on information disclosure", https://gridcom-rt.ru/

10. Site of Elecon JSC, section "on information disclosure", https://zavod-elecon.ru/

11. V.A. Malyshenko, K.A. Malyshenko, Economic and Social Changes: Facts, Trends, Forecast, 2, 127 (2018) 